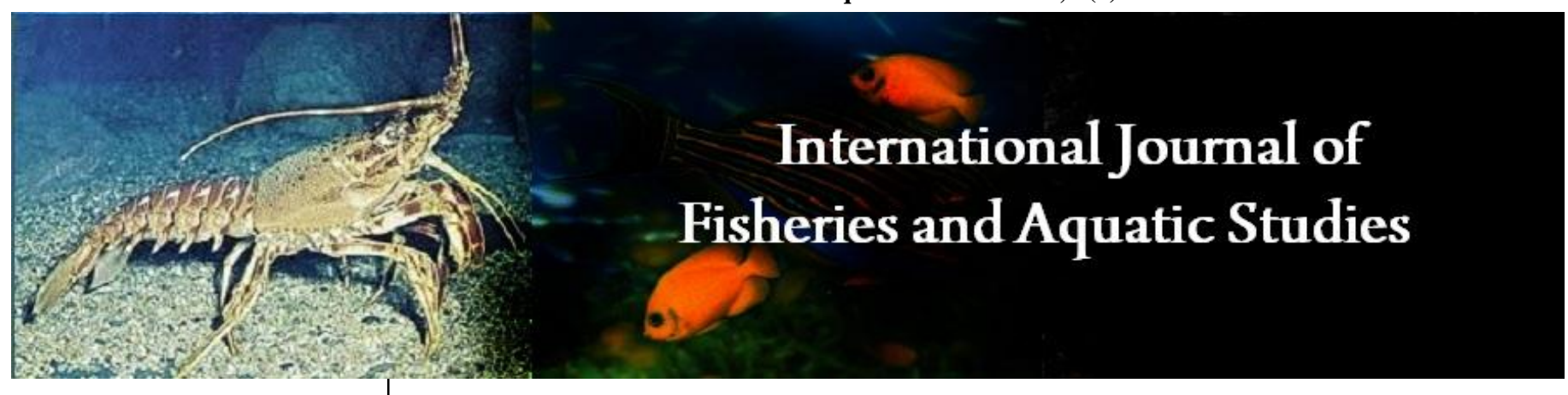

E-ISSN: 2347-5129

P-ISSN: 2394-0506

(ICV-Poland) Impact Value: 5.62

(GIF) Impact Factor: 0.549

IJFAS 2021; 9(1): 235-239

(C) 2021 IJFAS

www.fisheriesjournal.com

Received: 25-11-2020

Accepted: 27-12-2020

Anifowose Olayinka Remilekun Department of Veterinary

Medicine, Faculty of Veterinary

Medicine, University of Ibadan,

Nigeria

Oladosu Gbolahanmi Akinola Department of Veterinary Medicine, Faculty of Veterinary Medicine, University of Ibadan, Nigeria

Oladele Oludotun Olubusola Department of Veterinary Medicine, Surgery and

Radiology, Faculty of Veterinary

Medicine, University of Jos,

Nigeria

Corresponding Author:

Anifowose Olayinka Remilekun Department of Veterinary

Medicine, Faculty of Veterinary Medicine, University of Ibadan, Nigeria

\section{Causal factors of mass mortality of hatchery reared Clarias gariepinus fry during exogenous feeding}

\author{
Anifowose Olayinka Remilekun, Oladosu Gbolahanmi Akinola and \\ Oladele Oludotun Olubusola
}

DOI: https://doi.org/10.22271/fish.2021.v9.i1c.2409

\begin{abstract}
The study investigated the causal factors associated with mass mortality of hatchery-reared Clarias gariepinus Burchell 1822 fry during exogenous feeding. A feeding trial and fry re-infection trial were conducted using four different starter diets. The food samples were fed to 480 post-yolk-absorbed fries for 21 days in two replicates. Samples of dead fry were cultured for bacteria using standard methods. The total aerobic and coliform were significantly higher in all food samples, meanwhile, alkaline $\mathrm{pH}$ $(9.25 \pm 0.34)$ and low dissolved oxygen $(4.5 \pm 1.08)$ were not significantly different $(P>0.05)$ in all water tanks. The bacterial pathogens isolated from dead fries were Aeromonas hydrophila Stainer, 1943 and Pseudomonas aeruginosa Migula, 1990, whereas significantly higher mortality in experimentally infected fry was observed $(\alpha<0.05)$.

Mass mortality of C.gariepinus fry observed in this study was associated with bacterial pathogens, bacterial contamination of food, alkaline $\mathrm{pH}$, and low dissolved oxygen.
\end{abstract}

Keywords: fry, mortality, food samples, Clarias gariepinus, $\mathrm{pH}$

\section{Introduction}

Aquaculture, which is dominated by African catfish farming, has in recent decades increased at a phenomenal rate in many parts of the country, including Southwest Nigeria [19]. Fertilization, hatching, and early survival of larvae are vital for successful aquaculture of the African catfishes and this has been investigated earlier ${ }^{[5]}$. It has been estimated that $10 \%$ of all cultured aquatic animals are lost as a result of infectious disease ${ }^{[18]}$, meanwhile, environmental circumstances such as poor water quality, fluctuations in temperature, poor nutrition, overcrowding, poor handling, and transportation are common in intensive fish farming could pose stressful conditions to fish and make them more susceptible to a wide variety of pathogens. Hatchery propagation of fish seeds is sometimes hampered by mass mortality during fry nursing, with environmental factors, first feed sources, and infectious agents exerting great influence in this regard ${ }^{[9]}$. Mass mortality of fry would result in poor fingerling harvest and hence inadequate supply of fish seed which will, in turn, result in inadequate fish production. The suitability of first feed sources for fry rearing is very important in the light of the need for good growth and high survival rates ${ }^{[3]}$ and the high cost of importing encapsulated artemia has necessitated the search for other first feed sources with fish culturists using several materials to rear the larvae of Clarias gariepinus ${ }^{[2]}$. The studies on the causal factors of Clarias gariepinus fry mortality following exogenous feeding in Nigeria have not been reported. Therefore, this study sets out to investigate the causal factors of mass mortality of hatchery-reared C.gariepinus fry during exogenous feeding.

\section{Materials and Methods}

\subsection{Handling of experimental Fish}

Ethical clearance and valid approval were obtained from the University of Ibadan, Ethical Committee for Medical and Scientific Research before the commencement of the experiment. Fry used in this study were handled according to the Canadian Council on Animal Care's Guide to the Care and Use of Experimental Animals ${ }^{[10]}$. 


\subsection{Collection of Samples}

The feed samples collected were identified as follows: commercial Skretting gemma wean feed (Group 1 Durante $^{\mathrm{R}}$ ), Group 2 (Artemia Inve $\mathrm{R}^{\mathrm{R}}$; decapsulated or Shell Free Artemia), Group 3 (Dried-ground Shrimp), and Group 4 (Artemia Lush $^{\mathrm{R}}$; decapsulated or Shell Free Artemia). The microbial analysis of all the feed samples was carried out. Four hundred and eighty pieces of 3 days old African catfish fries were collected from the University of Ibadan fish farm, transported under hygienic conditions to the Department of Veterinary Medicine (Fish Medicine Unit). The fries were divided into four groups of forty fish each in three subgroups. Group 1 had subgroups 1a, 1b, and 1c, fed with commercial Skretting gemma wean diet, group 2 had subgroups $2 \mathrm{a}, 2 \mathrm{~b}$, and $2 \mathrm{c}$, fed with shell-free artemia Inve ${ }^{R}$, group 3 had subgroups $3 a, 3 b$, and $3 c$, fed with Dried-ground Shrimp, while group 4 had subgroups 4a, 4b, and 4c, fed with shell-free Artemia Lush ${ }^{\mathrm{R}}$. The experimental fries were stocked in a $6 \mathrm{~L}$ experimental plastic tank containing 4 liters of water $(100 \mathrm{ml}$ of water per fry). The feeding started third-day post-hatch and they were fed $0.03 \mathrm{~g}$ of feed per fry daily for 21 days

The fifty percentage of water in each experimental fish tank was changed every 48 hours to avoid the death of fries due to poor water quality $\left({ }^{25}\right)$. Water quality parameters namely $\mathrm{pH}$, Dissolved Oxygen, Ammonia, Nitrite, and Total Hardness was measured on days 11 and 21 using digital $\mathrm{pH}$ meter, Dissolved Oxygen meter, chemical titration for total hardness, and ELISA reader (ELX 800 from Biotek) for the optical density of color development for ammonia and nitrite.

Every forty-eight hours, mortality rates were monitored and recorded. Clinical Signs of infectious diseases were also observed.

Dead fries were daily collected from each experimental tank and bacteriology carried out on freshly dead fries from each group at the Veterinary Diagnostic Laboratory of Animal Care Consult Ibadan.

\subsection{Bacterial cultures and preparation of inoculum}

The swabs from homogenized tissues of topically sterilized fries carcasses were streaked on nutrient agar, MacConkey agar, Thiosulfate-citrate-bile-salts-sucrose agar and incubated at $37^{\circ} \mathrm{C}$ for 24 hours and 48 hours respectively while their identities were confirmed using standard techniques as described by Olutiola et al., ${ }^{[20]}$ as outlined. The bacteria isolates were further identified based on the results of various biochemical tests using Bergey's Manual of Systemic Bacteriology [27] and Global Infectious Diseases and Epidemiology Network (GIDEON) Online microbiology database ${ }^{[14]}$

The fries re-infection trail was done by homogenizing the surface of identified bacteria isolates in sterile phosphatebuffered saline (PBS) and the turbidity adjusted to correspond to $0.5 \mathrm{McF}$ arland's turbidity standard equivalent to $1 \mathrm{X} 10^{8}$ $\mathrm{cfu} / \mathrm{ml}^{[4]}$

\subsection{Experimental fry re-infection}

Two hundred and forty pieces of fries were divided into three groups and 6 subgroups of forty fries, and were infected by immersing fish in water containing 1 X $10^{8} \mathrm{cfu} / \mathrm{ml}$ of the isolates at the rate of $1 \mathrm{ml} / \mathrm{L}$ as follows: subgroups $1 \mathrm{a}$ and $1 \mathrm{~b}$ were infected with isolates of Aeromonas hydrophila, subgroups $2 \mathrm{a}$ and $2 \mathrm{~b}$ were infected with isolates of
Pseudomonas aeruginosa, subgroups $3 \mathrm{a}$ and $3 \mathrm{~b}$ were the control group and they were not infected. The fries were fed the same amount of feed, $0.03 \mathrm{~g}$ of feed per fry making $1.2 \mathrm{~g}$ per fish tank for 16 days and half of the water was replaced at 24 hour-interval to further ensure good water quality ${ }^{[25]}$. The Total Hardness, Ammonia, Nitrite, $\mathrm{pH}$ and Dissolved oxygen concentration of the water was monitored and recorded at 8 days interval during the period of this study ${ }^{[12]}$.

The experimentally-infected fries were observed daily for 16 days. Clinical signs, skin lesions, mortalities, and the quality parameters of water were noted and recorded. Dead fries from the experimental infection trials were processed for reisolation of Infective bacterial isolates. A positive culture was confirmed if the morphology and biochemical characteristics of the re-isolated strain were identical with those of the isolates used in the experimental infection

\subsection{Statistical analysis}

The water quality parameters in different experimental tanks during the feeding trial and fry re-infection trial with bacteria isolates were determined and the analysis of variance (ANOVA) was used to determine the level of statistical significance in all four water tanks. The analysis of variance (ANOVA) was also used to determine the level of significance in mortality rate during fries re-infection trial with bacterial isolates, a $\mathrm{p}$-value of less than $0.05(p<0.05)$ was considered as significant.

\section{Results}

The physicochemical findings such as $\mathrm{pH}$, Total hardness, Nitrite, Ammonia, and Dissolved oxygen in all fish tanks during the feeding trial were not significantly different at $95 \%$ confidence limit $(p>0.05)$ as indicated in Table 1, meanwhile, the physicochemical findings such as $\mathrm{pH}$, Total hardness, Nitrite, Ammonia, and Dissolved oxygen in all fish tanks during the re-infection trial were significantly different at $95 \%$ confidence limit $(p<0.05)$ as indicated in Table 1 . All the feed samples had high total aerobic bacteria counts and were not significantly different at $95 \%$ confidence limit $(p>0.05)$ as indicated in Table 2.

The mortality rate was increasing daily during the feeding trial in which the fries group fed with dried shrimp (group 3) had the highest $(98.3 \%)$, followed by the fries group fed with Artemia Lush® (group 4) $97.5 \%$ and $79.1 \%$ in fish tanks fed with Artemia Inve ${ }^{\circledR}$ (group 2) respectively while the mortality rate of fries group fed with commercial Skretting gemma wean diet (group 1) was $35.8 \%$ as indicated in Table 3 . The values for the total mortality rate of all the fry groups were significantly different at $95 \%$ confidence limit $(p<0.05)$ as indicated in Table 3.

There was an increase in the mortality rate daily during the fry re-infection trial period, fry group infected with Pseudomonas aeruginosa had the highest mortality rate $78 \%$, while, $74 \%$ mortality rate was observed in the group infected with Aeromonas hydrophila while the control group had the lowest mortality rate of $6.3 \%$ as indicated in Table 3 .

The values for the total mortality rate of all the infected groups were significantly different at $95 \%$ confidence limit $(p<0.05)$ as indicated in Table 3.

The bacterial isolates from dead fries during the feeding trial and re-infection trial were Aeromonas hydrophila and Pseudomonas aeruginosa as indicated in Table 4. 
Table 1: Physicochemical findings of experimental water tanks during feeding trial and re-infection trial

\begin{tabular}{|c|c|c|c|c|c|}
\hline Physicochemical Parameters & Day 11 post-feeding trial & $\begin{array}{c}\text { Day 21 post- } \\
\text { feeding trial }\end{array}$ & $\begin{array}{c}\text { Day 8 post- } \\
\text { re-infection trial }\end{array}$ & $\begin{array}{c}\text { Day 16 post } \\
\text {-re-infetion trial }\end{array}$ & $\begin{array}{c}\text { Standard Values for Fish } \\
\text { Farming APHA 1989, Boyd and Tucker 1992 }\end{array}$ \\
\hline pH & $9.25 \pm 0.34^{\mathrm{b}}$ & $8.98 \pm 0.38^{\mathrm{b}}$ & $8.36 \pm 1.15^{\mathrm{a}}$ & $8.4 \pm 1.23^{\mathrm{a}}$ & \\
\hline Total Hardness (ppm) & $121.3 \pm 2.5^{\mathrm{b}}$ & $165 \pm 12.9^{\mathrm{b}}$ & $143 \pm 40.4^{\mathrm{a}}$ & $130 \pm 17.3^{\mathrm{a}}$ & \\
\hline Nitrite (ppm) & $0.13 \pm 0.008^{\mathrm{b}}$ & $0.18 \pm 0.006^{\mathrm{b}}$ & $0.023 \pm 0.006^{\mathrm{a}}$ & $0.02 \pm 0.001^{\mathrm{a}}$ & \\
\hline Ammonia (ppm) & $0.57 \pm 0.22^{\mathrm{b}}$ & $1.58 \pm 0.23^{\mathrm{b}}$ & $0.84 \pm 0.68^{\mathrm{a}}$ & $0.88 \pm 0.70^{\mathrm{a}}$ & \\
\hline Dissolved Oxygen (ppm) & $4.5 \pm 1.1^{\mathrm{b}}$ & $4.5 \pm 1.08^{\mathrm{b}}$ & $4.53 \pm 1.01^{\mathrm{a}}$ & $4.50 \pm 0.87^{\mathrm{b}}$ & $0.05 \mathrm{max}$ \\
\hline
\end{tabular}

Values with $\left(^{b}\right)$ across row are not significantly different at $95 \%$ confidence limit $(p>0.05)-$ ANOVA, $\min =\operatorname{minimum}$, max $=$ maximum

Values with $\left({ }^{\mathrm{a}}\right)$ across row are significantly different at $95 \%$ confidence limit $(p<0.05)$ - ANOVA

Table 2: Microbial Analysis of Feed Samples

\begin{tabular}{|c|c|c|c|c|}
\hline Parameters & $\begin{array}{c}\text { Group 1 Feed } \\
\text { cfu/g x 10 }\end{array}$ & $\begin{array}{c}\text { Group 2 Feed } \\
\text { cfu/g x10 }^{\mathbf{5}}\end{array}$ & $\begin{array}{c}\text { Group 3 Feed } \\
\text { cfu/g x 10 }^{\mathbf{5}}\end{array}$ & $\begin{array}{c}\text { Group 4 Feed }^{\text {cfu/g x 10 }} \\
\text { cfu }^{\mathbf{5}}\end{array}$ \\
\hline Total Aerobic Counts & $1.18^{\mathrm{a}}$ & $7.68^{\mathrm{a}}$ & $2.18^{\mathrm{a}}$ & $4.39^{\mathrm{a}}$ \\
\hline Total Coliform Counts & $1.19^{\mathrm{a}}$ & $3.06^{\mathrm{a}}$ & $1.10^{\mathrm{a}}$ & $3.75^{\mathrm{a}}$ \\
\hline
\end{tabular}

Values with $\left({ }^{a}\right)$ across the column are not significantly different at $95 \%$ confidence limit $(p>0.05)$ - ANOVA

Table 3: Percentage mortality of fry during the feeding trial and re-infection trial

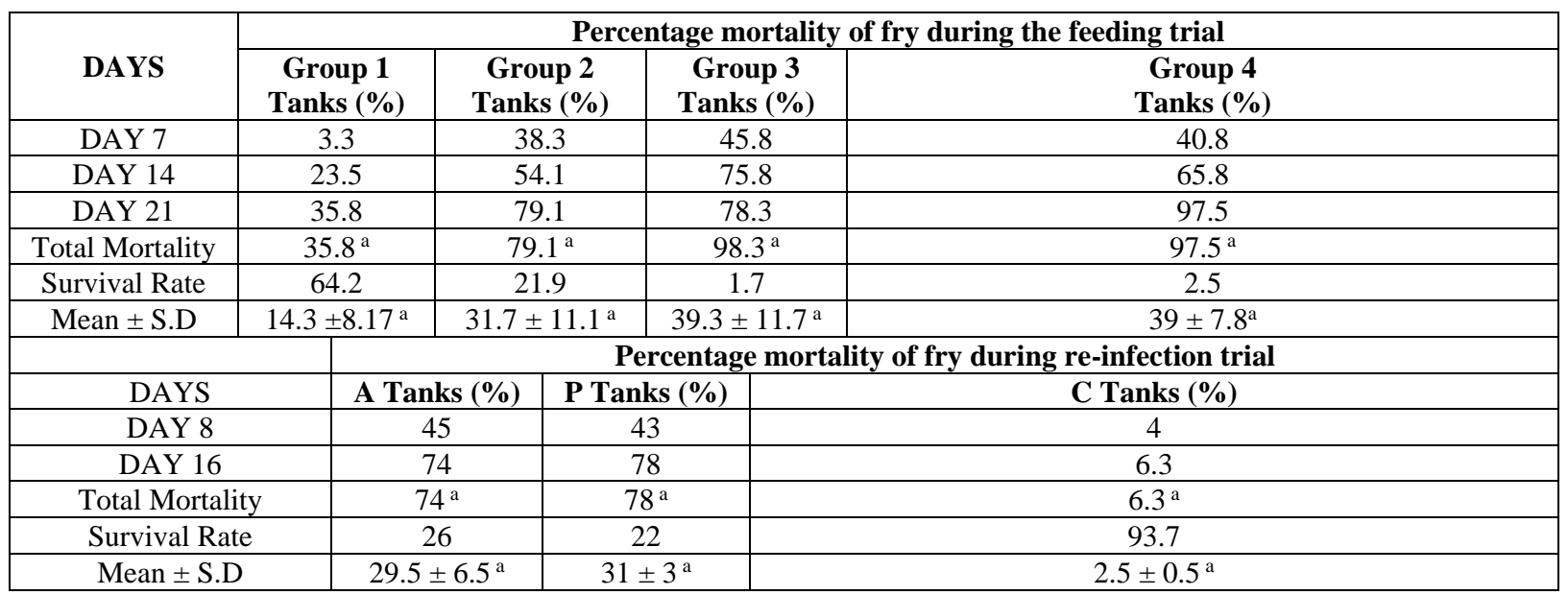

Table 4: Bacteria Associated with fry mortality during the feeding trial

\begin{tabular}{|c|c|c|c|c|c|c|c|c|c|c|c|c|c|c|c|c|c|c|}
\hline Bacterial isolates from each group & Gram-Staining & Mo & Mc & $\mathbf{C O}$ & $\mathbf{S C}$ & & MR & $\mathbf{V P}$ & H] $\mathbf{I}$ & T & $\Gamma$ & $\mathbf{C H}$ & GH & SH & MS & $\mathbf{G I}$ & & $\mathbf{L} \mathbf{S}$ \\
\hline Group 1 (Pseudomonas aeruginosa) & Gram-negative rod -shaped & + & NLF & ++ & + & & - & - & - & & + & + & + & - & - & - & - & -- \\
\hline Group 2 (Pseudomonas aeruginosa) & Gram -negative rod-shaped & + & $\mathrm{NLF}$ & ++ & + & & - & - & - & & + & + & + & - & - & - & - & -- \\
\hline Group 3 (Aeromonas hydrophila) & Gram-negative rod -shaped & + & LF & ++ & - & + & + & - & - & & + & - & - & - & - & + & + & +- \\
\hline Group 4 (Pseudomonas aeruginosa) & Gram-negative rod -shaped & + & NLF & ++ & + & - & - & - & - & & \pm & + & + & - & - & - & - & -- \\
\hline Group 4 (Aeromonas hydrophila) & Gram-negative rod-shaped & + & LF & ++ & - & + & + & + & - & & + & - & - & - & - & & & +- \\
\hline
\end{tabular}

Mo = Motility, Mc = Macconkey agar, C = Catalase, $\mathbf{O}=$ Oxidase, $\mathbf{S c}=$ Simon citrate, $\mathbf{I}=$ indole, MR = Methyl red, VP = Voges Proskauer, $\mathbf{H}$ $=\mathrm{H}_{2} \mathrm{~S}$ production, $\mathbf{E}=$ Eosine methylene blue, $\mathbf{T}=$ Thiosulfate-citrate-bile salts-sucrose agar, $\mathrm{U}=$ Urease, $\mathbf{C H}=\mathrm{Casein} \mathrm{Hydrolysis}, \mathbf{G H}=$ Gelatin hydrolysis, $\mathbf{S H}=$ Starch hydrolysis, $\mathbf{M S}=$ Manitol salt agar, $\mathbf{G}=$ Glucose, $\mathbf{M}=$ Maltose, $\mathbf{L}=$ Lactose, $\mathbf{S}=$ Sucrose, $\mathbf{L F}=$ Lactose Fermenter NLF $=$ Non Lactose Fermenter.

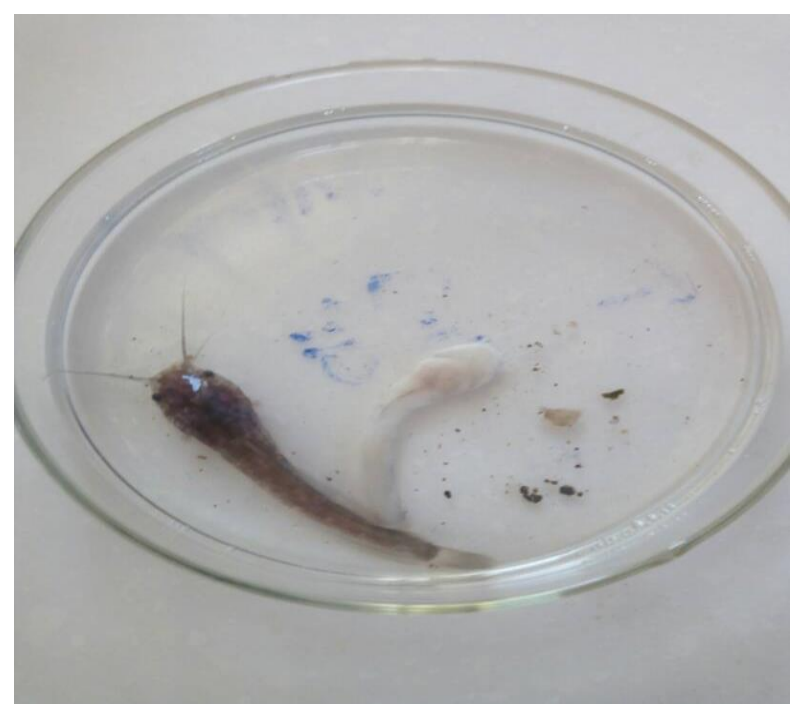

Fig 1: Dead fry

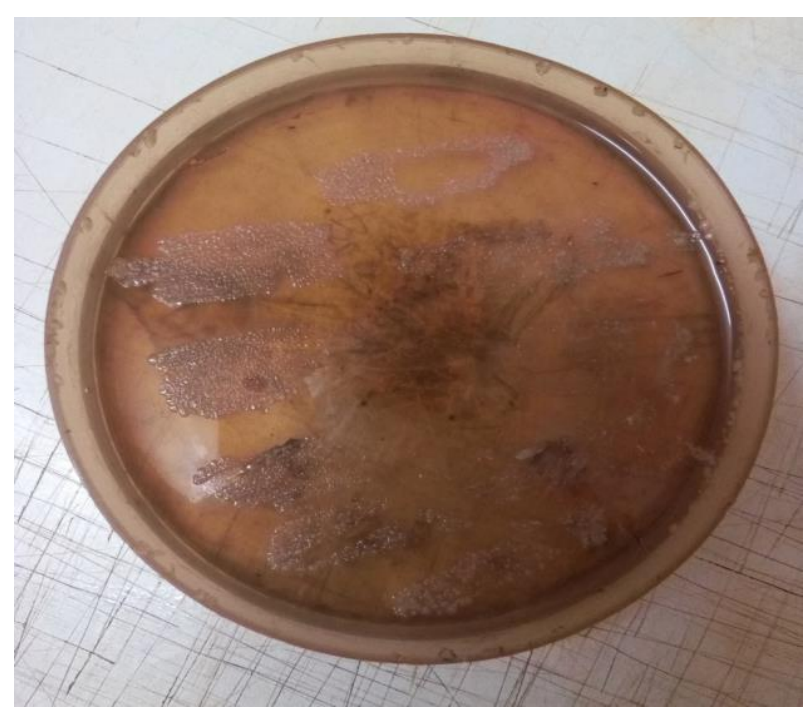

Fig 2: TSA agar of bacterial Isolates 


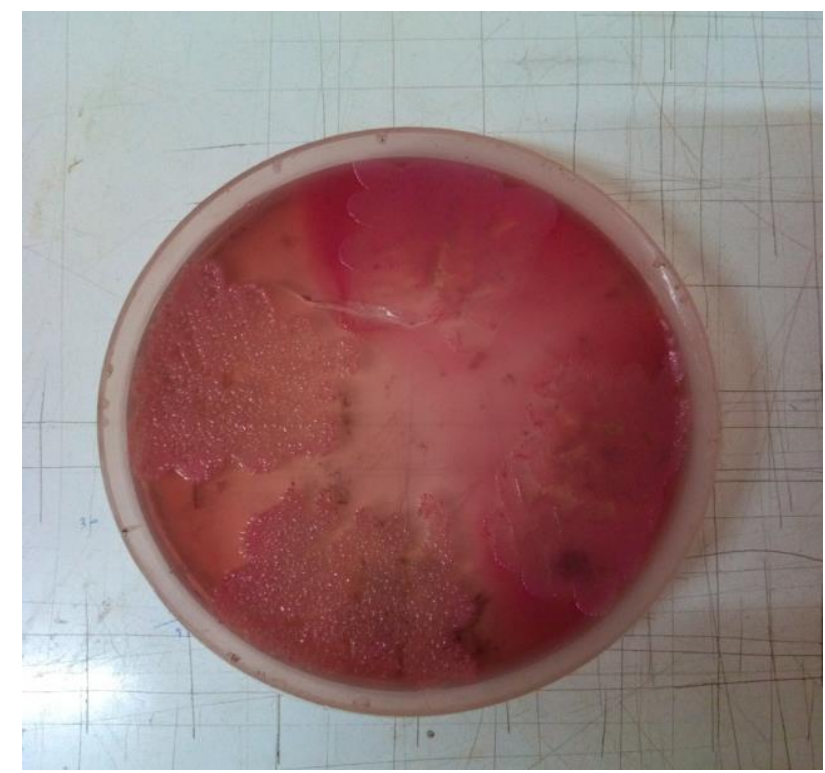

Fig 3: Macconkey Agar of Bacteria Isolates

\section{Discussion}

In the feeding trial, the $\mathrm{pH}$ values of water observed in this study on day 12 in the water tanks fed with four first feed sources were alkaline as indicated in Table 1. The alkaline $\mathrm{pH}$ values persisted for the whole 21 days in this study. The fishes can become stressed in water with a $\mathrm{pH}$ ranging from 4.0 to 6.5 and 9.0 to $11.0^{[13]}$. The $\mathrm{pH}$ observed in this study was higher than 8.5 and this high alkaline $\mathrm{pH}$ may contribute to mass mortality of fry observed in this study during the feeding trial as indicated in Table 3.

Dissolved Oxygen affects the growth, survival, distribution, behavior, and physiology of fish ${ }^{[22]}$. Oxygen depletion in water leads to poor feeding of fish, starvation, reduced growth, and more fish mortality, either directly or indirectly [7]. According to Banerjea [6], dissolved oxygen for average fish production should be above 5ppm, and dissolved oxygen $1-3$ ppm has a sublethal effect on growth and feed utilization [8].

Low dissolved oxygen was observed in this study within the first 21 days in fry groups fed with artemia (group $2 \& 4$ ) and shrimp (group 3) as indicated in Table 1 and this may be as a result of environmental temperature which decreases oxygen solubility and increase the metabolism of tank organisms, subsequently increasing the biological oxygen demand. Chronic environmental hypoxia as observed in this study caused stress, reduced feed consumption, slow growth, and high mortalities ${ }^{[25]}$ (Table 3, Figure 1). Ubiebi ${ }^{[26]}$ reported higher bacteria loads in fish feeds; Durante ${ }^{\mathrm{R}}\left(3.3 \times 10^{5} \mathrm{cfu} / \mathrm{g}\right)$, Aqua $^{\mathrm{R}}\left(1,75 \times 10^{5} \mathrm{cfu} / \mathrm{g}\right), \mathrm{Multi}^{\mathrm{R}}\left(3.3 \times 10^{5} \mathrm{cfu} / \mathrm{g}\right)$, and these were similar to the high level of bacteria contamination recorded in all four first food sources in this study as indicated in Table 2, meanwhile, Kings et al., ${ }^{[16]}$ had earlier reported that ingestion of contaminated feed may be a source of Aeromonas Hydrophila infection in catfish.

The fry in group two during the feeding trial had high mortality of $70.8 \%$ as indicated in Table 3, which may be attributed to the high level of bacterial count $\left(7.68 \times 10^{5}\right.$ $\mathrm{cfu} / \mathrm{g}$ ) in the feed sample as indicated in Table 2.

The high percentage mortality $70.8 \%$ and $97.5 \%$ observed during feeding trial for fry fed with Artemia in group 2 and group 4 as indicated in Table 3 is similar to the observation of Adewolu et al. ${ }^{[1]}$ who recorded mortality of $66.7 \%$ for fry fed with Artemia. The highest percentage mortality (98.3\%)
Table 3, observed in the fry group fed with shell-free Artemia (group 4) in this study may be attributed to bacterial contamination of water through feed since the highest bacteria load $\left(7.8 \times 10^{5} \mathrm{cfu} / \mathrm{g}\right)$ was observed in the food source (Table 2).

The bacteria isolated and identified from freshly dead fry from all the four groups based on microbial and biochemical characterization were Pseudomonas aeruginosa and Aeromonas hydrophila (Table 4, Figure 2, and 3).

The high mortality observed in the re-infection trial with the bacterial isolates, and the re-isolation of these pathogens from freshly dead fry tend to lend credence to the culpability of the bacterial pathogens.

The most important fish pathogen was Aeromonas hydrophila ${ }^{[11]}$ and the highest prevalence is in polluted waters ${ }^{[15]}$. The mortality rate of $73.7 \%$ (Table 3) was observed in the fry group infected with Aeromonas hydrophila in this study. This is similar to the report of Anyanwu et al., ${ }^{[4]}$ who observed a cumulative mortality rate of $30-90 \%$ in catfish infected with Aeromonas hydrophila at the rate of $1 \times 10^{8} \mathrm{cfu} / \mathrm{ml}$ of the pond water. In Bangladesh, Sarkar et al., ${ }^{[21]}$ also reported 60$80 \%$ mortality at day 15 post-infection in catfish with Aeromonas hydrophila. The variation in the pattern and mortality rates may be related to the species of fish, the strain of Aeromonas species, experimental conditions, the dose of the infective pathogen given, route of administration of the pathogen, and duration of the experiment ${ }^{[4]}$.

Catfish are reported to be susceptible to Pseudomonas spp, with moderate to high losses ${ }^{[23]}$. The percentage mortality of fry re-infected with Pseudomonas aeruginosa in this study was 77.5 (Table 3). In the fry re-infection trial, fry re-infected with Pseudomonas aeruginosa had the lowest mortality (Table 3), and this may be due to the incrimination of Pseudomonas aeruginosa as the most common bacterial infection among fish and appear to be the stress-related disease of freshwater fish under culture conditions ${ }^{[17]}$. The results of the feeding trial and fry re-infection trial in this study are similar to each other concerning poor water quality, high percentage mortality, and presence of bacteria isolates. Therefore, causal factors of mass mortality of hatchery-reared fry during exogenous feeding include poor water quality, feed contamination, and the presence of bacterial pathogens.

\section{Conclusion}

Factors that were observed to predispose the African catfish fry to mass mortality are bacterial contamination of feed sources, extremes of water quality parameters like $\mathrm{pH}$ (alkaline), and low dissolved oxygen.

Bacterial pathogens associated with mass mortality in the African Catfish nursing during exogenous feeding are Aeromonas hydrophila and Pseudomonas aeruginosa.

\section{References}

1. Adewolu MA, Akintola SL, Akinwunmi OO. Growth Performance And Survival of Hybrid African Catfish Larvae (Clarias Gariepinus X Heterobranchus Bidorsalis) fed on Different Diets. African Journals Online 2009;7(2009):45-51.

2. Adewumi AA, Olaleye VF. Catfish Culture in Nigeria; Progress, prospects and problems. African Journal of Agricultural Research 2011;6(6):1281-1285.

3. Adeyemo AA, Oladosu GA, Ayinla AO. Growth and Survival of fry of African catfish Species, Clarias Gariepinus Burchell, Heterobranchus Bidorsalis 
Geoferry and Heteroclarias reared on Moina dubia in comparison with other feed sources. Aquaculture. 1994;119(1):41-45.

4. Anyanwu MU, Chah KF, Shoyinka VS. Evaluation of pathogenicity of motile Aeromonas species in African catfish. International Journal of Fisheries and Aquatic Studies 2015;2(3):93-98.

5. Ataguba GA, Annune PA, Ogbe FG. Induce breeding and early growth of progeny from crosses between African clariid fishes, Clarias gariepinus (Burchell 1822), and Heterobranchus longifilis under Hatchery condition. Journal of Applied Bioscience 2009;14:755-760.

6. Banerjea SM. Water quality and soil condition of fishponds in some states of India in relation to fish production, Indian Journal of Fisheries 1967;14:115 -144.

7. Bhatnagar A, Garg SK. Causative factors of fish mortality in still water fish ponds under sub-tropical conditions, Aquaculture 2000;1(2):91-96.

8. Bhatnagar A, Jana SN, Garg SK, Patra BC, Singh G, Barman UK. Water quality management in aquaculture, course manual of a summer school on the development of sustainable aquaculture technology in fresh and saline waters. CCS Haryana Agricultural, Hisar (India) 2004, 203-210.

9. Bricknell L, Dalmo RA. The use of Immunostimulants in fish larval aquaculture. Journal of Fish and Shellfish immunology 2005;19(2005):457-472.

10. Canadian Council on Animal Care (CCAC). Guide to the care and use of experimental animals. Edn Ottawa, Ontario, Canada, 1993;2(1):16-18.

11. Carnahan AM, Altwegg M. Taxonomy. In Austin B et al., Eds. The genus Aeromonas, John Wiley, Chichester, UK, 1996, 1-38.

12. Clesceri IS, Greenberg AE, Trussell RR. Standard methods for the examination of water and wastewater. Edn 17, American Public Health Association (AWWA) Washington D.C USA, 1989.

13. Ekubo AA, Abowei JFN. Review of some water quality management principles in culture fisheries. Research Journal of Applied Sciences, Engineering, and Technology 2011;3(2):1342-1357.

14. Global Infectious Diseases and Epidemiology Network Online Microbiology Database. http://www.gideononline.com. 28 May 2017.

15. Hazen TC, Fliermans RP, Hirsch RP, Esch GW. Prevalence and distribution of Aeromonas hydrophila in the United States. Applied and Environmental Microbiology 1978;36:731-738.

16. King CH, Shotts EB. Enhancement of Edwardsiella tarda and Aeromonas salmonicida through ingestion by the ciliated protozoan. Tetrahymena pyriformis. FEMS Microbiology Letters 1988;51:85-89.

17. Kitao T, Aoki T, Kukudome M, Kawano K, Wada Y, Muzumo Y. Serotyping of Vibrio anguillarum isolated from diseased freshwater fish in Japan. Journal of Fish Diseases 1993;6:175-181.

18. Leong JC, Fryer JL. Viral vaccines for aquaculture. Annual Review of Fish Diseases 1993;45:225-240.

19. Olatoye IO, Afisu B. Antibiotic Usage and Oxytetracycline Residue in African Catfish Clarias gariepinus in Ibadan, Nigeria. World Journal of Fish and Marine Sciences 2013;5(3):302-309.

20. Olutiola PO, Famurewa O, Sonntag HG. An introduction to General Microbiology: A Practical Approach. Hygiene
Institut der Universitat Heidelberg 1991.

21. Sakar MJA, Rashid MM. Pathogenicity of the bacterial isolate Aeromonas hydrophila to catfishes, carps, and perch. Journal of Bangladesh Agricultural University 2002;10:57-161

22. Solis NB. The Biology and Culture of Penaues Monodon, Department papers. SEAFDEC Aquaculture Department, Tigbouan, Boilo Philippines 1988, 3-36.

23. Somsiri T, Soontornvit S. Bacterial diseases of cultured tiger frog (Rana tigerina). In C.R. Lavilla-Pitogo and E.R. Cruz-Lacierda (eds.), Diseases in Asian Aquaculture IV, Fish Health Section, Asian Fisheries Society, Manila 2002.

24. Thomas J, Madan N, Nambi KSS, Majeed SA, Basha AN, Hameed ASS. Studies on ulcerative disease caused by Aeromonas caviae-like bacterium in Indian catfish, Clarias batrachus (Linn). Aquaculture 2013;376:146150.

25. Tucker CS. Water Quality. In: Channel Catfish Culture (CS Tucker, ed.), Elsevier, Amsterdam 1985;135-227.

26. Ubiebi $\mathrm{C}$. Isolation and identification of bacterial isolates from poultry and fish feeds sold in Abraka, Delta State, Nigeria. Journal of Industrial Technology 2017;2(1):1420.

27. Whitman N, Good fellow M, Kamfer P, Busse HJ, Trayilo M, Ludovig W et al., Bergey's Manual of Bacteriology. Edn Springer, Verlag, New York, 2012;2(5):323-557. 